\title{
Psathyrellins A-E, Antibacterial Guanacastane Diterpenoids from Mushroom Psathyrella candolleana
}

\author{
Han $\mathrm{Wu}^{1} \cdot$ Hui-Xiang Yang ${ }^{2} \cdot{\text { Zheng-Hui } \mathrm{Li}^{2} \cdot \text { Tao Feng }^{1,2} \text { - Ji-Kai Liu }}^{1,2}$
}

Received: 16 June 2021 / Accepted: 23 June 2021 / Published online: 6 July 2021

(c) The Author(s) 2021

\section{Abstract}

Five previously undescribed guanacastane diterpenoids, namely psathyrellins A-E (1-5), were obtained from cultures of the mushroom Psathyrella candolleana. Their structures with absolute configurations were elucidated by extensive spectroscopic methods. Compounds 1-3 showed antibacterial activity against four strains with MIC values in a range of 16-128 $\mu \mathrm{g} / \mathrm{mL}$.

\section{Graphic Abstract}

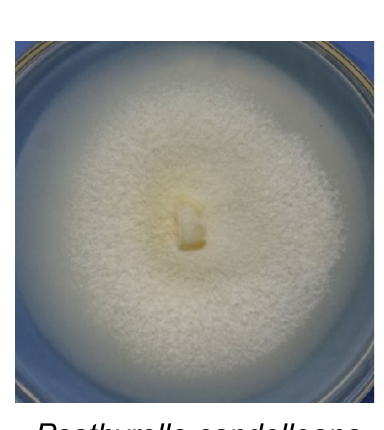<smiles>CC1=C2CC3=C(O)C(=O)[C@H](C(C)C)C3(C)CC[C@]2(C)C[C@@H]1O</smiles><smiles>CC1=C2C=C3C(=O)C(O)=C(C(C)O)C3(C)CC[C@]2(C)C[C@H]1O</smiles><smiles>CC(C)C1=C(O)C(=O)C2=CC3=C(CO)C(O)[C@@H](O)C[C@]3(C)CCC21C</smiles>

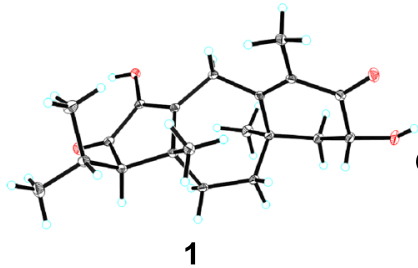

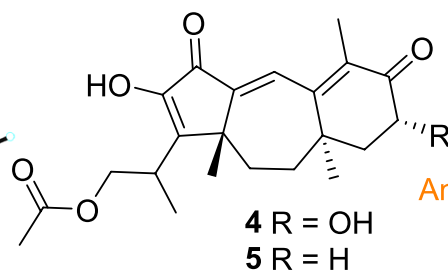

Keywords Psathyrella candolleana $\cdot$ Guanacastane diterpenoids · Antibacterial activity

\section{Introduction}

The basidiomycete Psathyrella candolleana (Psathyrellaceae) is a small agaric usually found in the vicinity of recently dead hardwood trees. It has a wide distribution on lawns or pastures in Europe and North America. Previous

Tao Feng

tfeng@mail.scuec.edu.cn

$\triangle$ Ji-Kai Liu

liujikai@mail.scuec.edu.cn

1 Anhui Key Laboratory of Modern Chinese Materia Medica, School of Pharmacy, Anhui University of Chinese Medicine, Hefei 230012, People's Republic of China

2 School of Pharmaceutical Sciences, South-Central University for Nationalities, Wuhan 430074, People's Republic of China pharmacological studies indicated that the extracts of $P$. candolleana showed a marked anticlastogenic effect against DNA damage [1-3], while chemical investigations on this fungus have demonstrated guanacastane-type diterpenoids $[4,5]$, which possess a unique $5 / 7 / 6$ tricyclic backbone that have been found only in several fungal species. These diterpenoids have been detected to possess antibacterial and cytotoxic properties [5-7]. As our long-term chemical studies on higher fungi [8-13], a chemical investigation on this mushroom resulted in the isolation of five new guanacastane diterpenoids, namely psathyrellins A-E (1-5, Fig. 1). Their structures were elucidated by extensive spectroscopic methods, while their absolute configurations were established by the single crystal X-ray diffraction and CD spectra. All compounds were evaluated for their antibacterial activity against 
<smiles>C=C1C(=O)[C@H](O)C[C@@]2(C)CC[C@@]3(C)C(=CC2=C1C)C(=O)C(O)=C3C(C)C</smiles><smiles></smiles><smiles>CC(=O)OCC(C)C1=C(O)C(=O)C2=CC3=C(C)C(=O)CC[C@]3(C)CC[C@]21C</smiles>

Fig. 1 Structures of compounds 1-5

four strains. Herein, the isolation, structural elucidation, and the biological activities of these isolates are reported.

\section{Results and Discussion}

Psathyrellin A (1) was isolated as colorless crystals. Its molecular formula was determined as $\mathrm{C}_{20} \mathrm{H}_{28} \mathrm{O}_{4}$ on the basis of HRESIMS at $\mathrm{m} / z 333.20584$ (calcd for $\mathrm{C}_{20} \mathrm{H}_{28} \mathrm{O}_{4}$ $[\mathrm{M}+\mathrm{H}]^{+}$, 333.30604), implying seven degrees of unsaturation. The IR absorption bands at 3421, 1710, 1640, $1462 \mathrm{~cm}^{-1}$ revealed the existence of hydroxy, carbonyl, and double bonds. In the ${ }^{1} \mathrm{H}$ NMR spectrum (Table 1), three singlets at $\delta_{\mathrm{H}} 1.06,1.09,1.85$, two doublets at $\delta_{\mathrm{H}} 0.79(3 \mathrm{H}$, $\mathrm{d}, J=6.9 \mathrm{~Hz}), 1.12(3 \mathrm{H}, \mathrm{d}, J=6.9 \mathrm{~Hz})$ were readily assigned for five methyl groups. In addition, one doublet at $\delta_{\mathrm{H}} 4.46$ $(1 \mathrm{H}, \mathrm{dd}, J=14.0,5.2 \mathrm{~Hz})$ indicated an oxidized methine carbon. In the ${ }^{13} \mathrm{C}$ NMR spectrum, a total of 20 carbon resonances were detected. They were classified into five $\mathrm{CH}_{3}$, four $\mathrm{CH}_{2}$, three $\mathrm{CH}$, and eight non-protonated carbons by

Table $1{ }^{1} \mathrm{H}$ NMR Data for $\mathbf{1 - 5}$ in Methanosl- $d_{4}(\delta$ in ppm, $J$ in $\mathrm{Hz})$

\begin{tabular}{llllll}
\hline No. & $\mathbf{1}$ & $\mathbf{2}$ & $\mathbf{3}$ & $\mathbf{4}$ & $\mathbf{5}$ \\
\hline 2 & $3.63, \mathrm{~m}$ & $6.99, \mathrm{br} \mathrm{s}$ & $7.07, \mathrm{~d}(2.2)$ & $7.03, \mathrm{q}(1.2)$ & $7.05, \mathrm{~d}(1.3)$ \\
& $3.46, \mathrm{~d}(0.9)$ & & & \\
5 & & & $4.12, \mathrm{~d}(7.9)$ & \\
6 & $4.46, \mathrm{dd}(14.0,5.2)$ & $4.55, \mathrm{dd}(14.0,5.4)$ & $3.86, \mathrm{ddd}(12.0,7.9,3.7)$ & $4.56, \mathrm{dd}(14.0,5.4)$ & $2.74, \mathrm{~m} ; 2.41, \mathrm{~m}$ \\
7 & $1.99, \mathrm{~m}$ & $2.11, \mathrm{dd}(12.9,5.4)$ & $1.74, \mathrm{dd}(13.0,3.8)$ & $2.11, \mathrm{dd}(12.9,5.5)$ & $2.06, \mathrm{dd}(13.5,4.4)$ \\
& $1.82, \mathrm{~d}(6.6)$ & $1.96, \mathrm{~m}$ & $1.65, \mathrm{t}(12.7)$ & $1.95, \mathrm{~m}$ & $1.92, \mathrm{~m}$ \\
9 & $2.26, \mathrm{td}(14.5,13.9,3.9)$ & $2.58, \mathrm{td}(14.3,3.1)$ & $2.27, \mathrm{ddd}(13.2,12.8,3.1)$ & $2.58, \mathrm{~m}$ & $2.45, \mathrm{~m}$ \\
& $1.57, \mathrm{~m}$ & $1.72, \mathrm{~m}$ & $1.57, \mathrm{~m}$ & $1.72, \mathrm{~m}$ & $1.89, \mathrm{~m}$ \\
10 & $1.79, \mathrm{~m}$ & $1.98, \mathrm{~d}(3.5)$ & $1.83, \mathrm{dt}(13.9,3.5)$ & $1.90, \mathrm{~m}$ & $1.76, \mathrm{dd}(13.7,3.1)$ \\
& $1.54, \mathrm{~m}$ & $1.70, \mathrm{q}(3.7)$ & $1.51, \mathrm{dd}(13.9,3.1)$ & $1.78, \mathrm{dd}(14.1,3.4)$ & \\
12 & $1.96, \mathrm{~d}(2.8)$ & & & & $1.71, \mathrm{~s}$ \\
15 & $1.85, \mathrm{~s}$ & $1.74, \mathrm{~s}$ & $4.19, \mathrm{~m}$ & $1.75, \mathrm{~s}$ & $1.08, \mathrm{~s}$ \\
16 & $1.09, \mathrm{~s}$ & $1.09, \mathrm{~s}$ & $0.97, \mathrm{~d}(11.1)$ & $1.11, \mathrm{~s}$ & $1.11, \mathrm{~s}$ \\
17 & $1.06, \mathrm{~s}$ & $1.11, \mathrm{~s}$ & $1.09, \mathrm{~d}(7.2)$ & $2.72, \mathrm{~m}$ & $2.70, \mathrm{~m}$ \\
18 & $2.05, \mathrm{~m}$ & $2.51, \mathrm{~m}$ & $2.5, \mathrm{~m}$ & $4.40, \mathrm{dd}(10.5,8.1)$ & $4.40, \mathrm{dd}(10.5,8.1)$ \\
19 & $0.79, \mathrm{~d}(6.9)$ & $1.29, \mathrm{dd}(10.4,6.9)$ & $1.29, \mathrm{~d}(6.9)$ & $4.30, \mathrm{dd}(10.5,7.1)$ & $4.30, \mathrm{dd}(10.5,7.2)$ \\
& & & & $1.27, \mathrm{~d}(6.9)$ & $1.27, \mathrm{~d}(7.0)$ \\
20 & $1.12, \mathrm{~d}(6.9)$ & $1.29, \mathrm{dd}(10.4,6.9)$ & $1.27, \mathrm{~d}(6.9)$ & $1.99, \mathrm{~s}$ & $1.99, \mathrm{~s}$
\end{tabular}


the DEPT and HSQC spectra (Table 2). Of them, two carbonyl signals at $\delta_{\mathrm{C}} 200.8$ (s, C-5) and 205.4 (s, C-13), and four olefinic signals four two double bonds at $\delta_{\mathrm{C}} 150.2$ (s, C-1), 162.5 (s, C-3), 130.5 (s, C-4), and 149.3 (s, C-14) occupied four degrees of unsaturation, suggesting a tricyclic backbone of $\mathbf{1}$. All these data, as well as the literature survey [5, 6, 14], suggested that $\mathbf{1}$ should be a guanacastane diterpenoid characterized with a 5/7/6-fused ring system. Preliminary analysis of 2D NMR data (especially the HMBC data) revealed two $\alpha, \beta$-unsaturated keto moieties in rings $\mathrm{A}$ and B, respectively (Fig. 2). A HMBC correlation from $\delta_{\mathrm{H}} 4.46(1 \mathrm{H}, \mathrm{dd}, J=14.0,5.2 \mathrm{~Hz}, \mathrm{H}-6)$ to $\mathrm{C}-5$, as well as a ${ }^{1} \mathrm{H}-{ }^{1} \mathrm{H}$ COSY correlation between $\mathrm{H}-6$ and $\mathrm{H}-7$, suggested a hydroxy group placed at C-6. After many attempts, a single crystal of 1 was obtained from methanol, while the single crystal X-ray diffraction revealed the absolute configuration of $\mathbf{1}$ as shown in Fig. 3 (Flack parameter $=0.05$ (3); CCDC: 2068966).

Psathyrellin B (2) was isolated as colorless crystals. Its molecular formula was determined as $\mathrm{C}_{20} \mathrm{H}_{26} \mathrm{O}_{4}$ by HRESIMS data at $\mathrm{m} / z 331.19031[\mathrm{M}+\mathrm{H}]^{+}$(calcd for $\mathrm{C}_{20} \mathrm{H}_{27} \mathrm{O}_{4}^{+}, 331.19039$ ). The UV data at $282 \mathrm{~nm}$ suggested a conjugated system in 2 . The $1 \mathrm{D}$ and $2 \mathrm{D}$ NMR spectra revealed similar patterns to those of $\mathbf{1}$ except that one more double bond in 2. In the HMBC spectrum, correlations from $\delta_{\mathrm{H}} 1.11\left(3 \mathrm{H}, \mathrm{s}, \mathrm{H}_{3}-17\right)$ to $\delta_{\mathrm{C}} 142.8(\mathrm{~s}, \mathrm{C}-1)$ and $158.6(\mathrm{~s}$,

Table $2{ }^{13} \mathrm{C}$ NMR Data for $\mathbf{1 - 5}$ in Methanol- $d_{4}(150 \mathrm{MHz}, \delta$ in ppm)

\begin{tabular}{|c|c|c|c|c|c|}
\hline No. & 1 & 2 & 3 & 4 & 5 \\
\hline 1 & $150.2, \mathrm{C}$ & $142.8, \mathrm{C}$ & 143.0, C & $142.7, \mathrm{C}$ & $142.9, \mathrm{C}$ \\
\hline 2 & $30.9, \mathrm{CH}_{2}$ & $129.0, \mathrm{CH}$ & $129.7, \mathrm{CH}$ & 129.1, CH & $129.2, \mathrm{CH}$ \\
\hline 3 & $162.5, \mathrm{C}$ & 158.6, C & $152.1, \mathrm{C}$ & $158.5, \mathrm{C}$ & $159.2, \mathrm{C}$ \\
\hline 4 & $130.5, \mathrm{C}$ & $131.5, \mathrm{C}$ & $138.5, \mathrm{C}$ & $131.6, \mathrm{C}$ & 133.6, C \\
\hline 5 & $200.8, \mathrm{C}$ & $200.8, \mathrm{C}$ & $75.0, \mathrm{CH}$ & $200.8, \mathrm{C}$ & $200.3, \mathrm{C}$ \\
\hline 6 & $69.8, \mathrm{CH}$ & $69.7, \mathrm{CH}$ & $71.0, \mathrm{CH}$ & $69.7, \mathrm{CH}$ & $34.5, \mathrm{CH}_{2}$ \\
\hline 7 & $50.2, \mathrm{CH}$ & $48.1, \mathrm{CH}_{2}$ & $47.2, \mathrm{CH}_{2}$ & $48.1, \mathrm{CH}_{2}$ & $39.3, \mathrm{CH}_{2}$ \\
\hline 8 & $41.8, \mathrm{C}$ & $39.2, \mathrm{C}$ & $39.1, \mathrm{C}$ & $39.2, \mathrm{C}$ & $38.1, \mathrm{C}$ \\
\hline 9 & $36.4, \mathrm{CH}_{2}$ & $35.7, \mathrm{CH}_{2}$ & $38.5, \mathrm{CH}_{2}$ & $35.7, \mathrm{CH}_{2}$ & $35.7, \mathrm{CH}_{2}$ \\
\hline 10 & $42.5, \mathrm{CH}_{2}$ & $31.5, \mathrm{CH}_{2}$ & $31.1, \mathrm{CH}_{2}$ & $31.6, \mathrm{CH}_{2}$ & $31.3, \mathrm{CH}_{2}$ \\
\hline 11 & $45.3, \mathrm{C}$ & $45.1, \mathrm{C}$ & $45.1, \mathrm{C}$ & $44.9, \mathrm{C}$ & $44.9, \mathrm{C}$ \\
\hline 12 & $62.9, \mathrm{CH}$ & $158.6, \mathrm{C}$ & $158.5, \mathrm{C}$ & 152.7, C & 152.7, C \\
\hline 13 & $205.4, \mathrm{C}$ & $152.2, \mathrm{C}$ & $139.5, \mathrm{C}$ & $152.8, \mathrm{C}$ & $152.7, \mathrm{C}$ \\
\hline 14 & 149.3, C & $190.1, \mathrm{C}$ & $190.8, \mathrm{C}$ & 189.9, C & 190.1, C \\
\hline 15 & $11.8, \mathrm{CH}_{3}$ & $12.3, \mathrm{CH}_{3}$ & $59.4, \mathrm{CH}_{2}$ & $12.3, \mathrm{CH}_{3}$ & $12.3, \mathrm{CH}_{3}$ \\
\hline 16 & $25.2, \mathrm{CH}_{3}$ & 27.3, $\mathrm{CH}_{3}$ & $26.7, \mathrm{CH}_{3}$ & $27.3, \mathrm{CH}_{3}$ & $26.2, \mathrm{CH}_{3}$ \\
\hline 17 & $17.1, \mathrm{CH}_{3}$ & $20.5, \mathrm{CH}_{3}$ & $20.4, \mathrm{CH}_{3}$ & $20.7, \mathrm{CH}_{3}$ & 21.0, $\mathrm{CH}_{3}$ \\
\hline 18 & $28.9, \mathrm{CH}$ & $27.3, \mathrm{CH}$ & $27.3, \mathrm{CH}$ & $32.3, \mathrm{CH}$ & $32.3, \mathrm{CH}$ \\
\hline 19 & $19.3, \mathrm{CH}_{3}$ & $20.6, \mathrm{CH}_{3}$ & $20.8, \mathrm{CH}_{3}$ & $67.1, \mathrm{CH}_{2}$ & $67.1, \mathrm{CH}$ \\
\hline 20 & 23.6, $\mathrm{CH}_{3}$ & 20.7, $\mathrm{CH}_{3}$ & 20.7, $\mathrm{CH}_{3}$ & $15.5, \mathrm{CH}_{3}$ & $15.5, \mathrm{CH}_{3}$ \\
\hline 21 & & & & $172.8, \mathrm{C}$ & 172.7, C \\
\hline 22 & & & & $20.8, \mathrm{CH}_{3}$ & $20.8, \mathrm{CH}_{3}$ \\
\hline
\end{tabular}

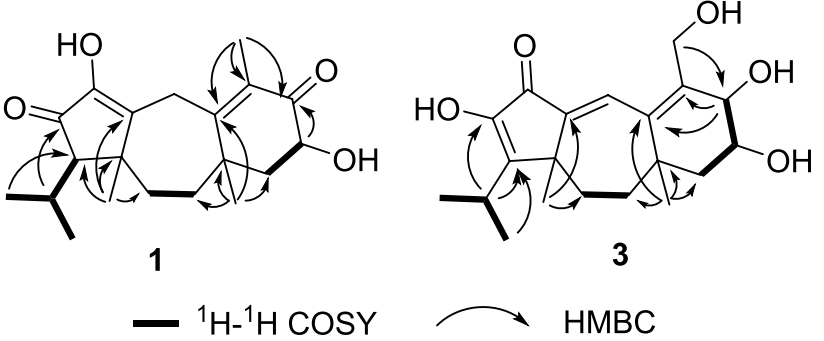

Fig. 2 Key ${ }^{1} \mathrm{H}-{ }^{1} \mathrm{H} \mathrm{COSY}$ and HMBC correlations of $\mathbf{1}$ and $\mathbf{3}$

C-12), from $\delta_{\mathrm{H}} 6.99(1 \mathrm{H}$, br s, $\mathrm{H}-2)$ to $\mathrm{C}-1$ and $\delta_{\mathrm{C}} 158.6$ (s, $\mathrm{C}-3)$, and from $\delta_{\mathrm{H}} 1.74\left(3 \mathrm{H}, \mathrm{s}, \mathrm{H}_{3}-15\right)$ to $\mathrm{C}-3$ and $\delta_{\mathrm{C}} 131.5$ (s, C-4) suggested that three double bonds were distributed at C-12/C-13, C-1/C-2, and C-3/C-4, respectively. Detailed analysis of 2D NMR data suggested that the other parts of 2 were the same to those of $\mathbf{1}$. A single crystal X-ray diffraction not only proved the planar structure, but also determined the absolute configuration of $\mathbf{1}$ as shown in Fig. 3 (Flack parameter $=-0.12(14)$; CCDC: 2068967$)$.

Psathyrellin $\mathrm{C}(\mathbf{3})$ was isolated as a yellow oil. The molecular formula was determined as $\mathrm{C}_{20} \mathrm{H}_{28} \mathrm{O}_{5}$ on the basis of HRESIMS data at $\mathrm{m} / z 349.20093[\mathrm{M}+\mathrm{H}]^{+}$(calcd for $\mathrm{C}_{20} \mathrm{H}_{29} \mathrm{O}_{5}^{+}, 349.20095$ ). All NMR data suggested that 3 was structurally similar to that of 2 (Fig. 2). In compound 3, C-15 was oxidized into a hydroxymethylene at $\delta_{\mathrm{C}} 59.4$. In addition, C-5 was reduced into a hydroxymethine at $\delta_{\mathrm{C}}$ 75.0. These information were supported by the HMBC and ${ }^{1} \mathrm{H}-{ }^{1} \mathrm{H}$ COSY data. In the ROESY spectrum, correlation of H-6 with $\mathrm{H}-9$ suggested that $\mathrm{OH}$ at C-6 should be $\alpha$ oriented. Based on this information, the coupling constant of $J_{5,6}=7.9 \mathrm{~Hz}$ indicated that the $\mathrm{OH}$ at $\mathrm{C}-5$ should be $\beta$ oriented. The CD spectrum of 3 revealed similar Cotton effects with those of 2 (Fig. 4), indicating the absolute configuration of $\mathbf{3}$ to be the same to that of $\mathbf{2}$.

Psathyrellin D (4) was isolated as a yellow oil. The molecular formula was determined as $\mathrm{C}_{22} \mathrm{H}_{28} \mathrm{O}_{6}$ on the basis of HRESIMS data at $\mathrm{m} / \mathrm{z} 411.17749$ [M+Na] $^{+}$(calcd for $\mathrm{C}_{22} \mathrm{H}_{28} \mathrm{O}_{6} \mathrm{Na}^{+}, 411.17781$ ). All spectroscopic data of $\mathbf{4}$ were similar to those of 2 excepted two additional carbons at $\delta_{\mathrm{C}}$ 20.8 (q) and 172.8 (s) in 4 that were easily assigned as an $O$-acetyl moiety. The HMBC correlations from $\delta_{\mathrm{H}} 4.40$ and
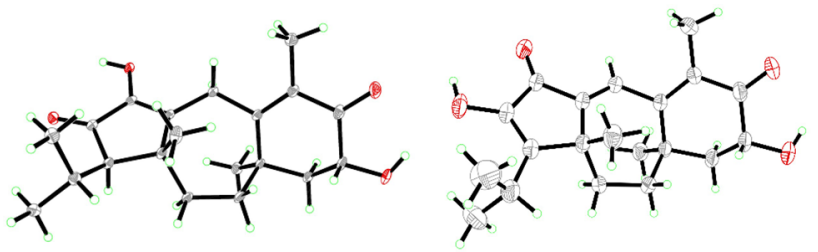

Fig. 3 ORTEP diagrams of $\mathbf{1}$ (left) and $\mathbf{2}$ (right) 


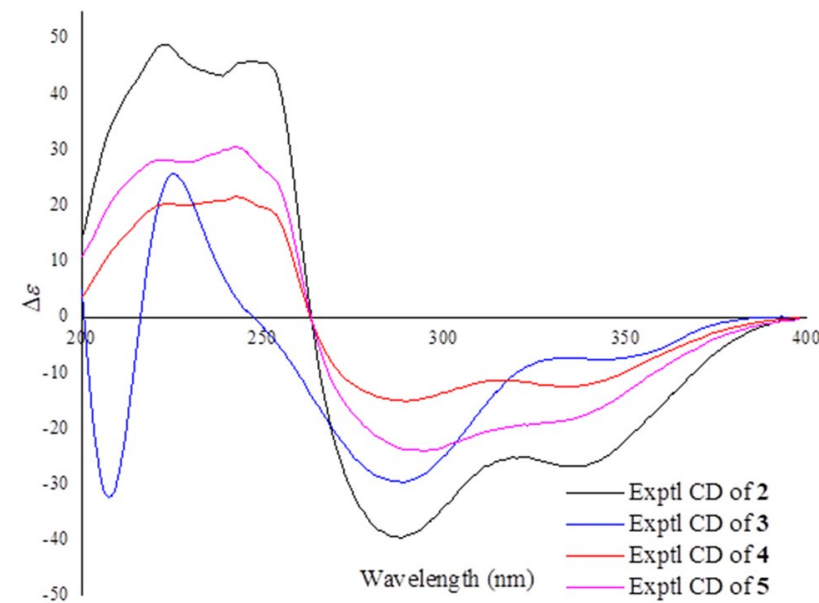

Fig. 4 CD curves of compounds $2-5$

4.30 to $\delta_{\mathrm{C}} 172.8(\mathrm{~s})$ and from $\delta_{\mathrm{H}} 1.27(3 \mathrm{H}, \mathrm{d}, J=6.9 \mathrm{~Hz}$, $\left.\mathrm{H}_{3}-20\right)$ to $\delta_{\mathrm{C}} 32.3$ (d, C-18), 67.1 (t, C-19) suggested that the $O$-acetyl moiety should be placed at C-19. Detailed analysis of 2D NMR data suggested that the other parts of $\mathbf{4}$ were the same to those of $\mathbf{2}$. The $\mathrm{CD}$ spectrum almost showed the same curve to that of $\mathbf{2}$, indicating the absolute configuration of the main backbone in $\mathbf{4}$ to be the same to that of $\mathbf{2}$ (Fig. 4). However, the stereochemistry of C-18 could not be established currently.

Psathyrellin E (5) was isolated as a yellow oil. The molecular formula was determined as $\mathrm{C}_{22} \mathrm{H}_{28} \mathrm{O}_{5}$ on the basis of HRESIMS data at $\mathrm{m} / z 373.20084[\mathrm{M}+\mathrm{H}]^{+}$(calcd for $\left.\mathrm{C}_{22} \mathrm{H}_{29} \mathrm{O}_{5}{ }^{+}, 373.20095\right)$. According to analysis of $1 \mathrm{D}$ and $2 \mathrm{D}$ NMR data, compound $\mathbf{5}$ was easily identified as a 19- $O$-acetyl derivative of $\mathbf{2}$, which was also similar to 4 . The only difference was that the hydroxymethine of C-6 in 4 was reduced into a methylene at $\delta_{\mathrm{C}} 34.5$ (t, C-6) in $\mathbf{5}$, as supported by the HMBC correlation from $\mathrm{H}-6$ to $\mathrm{C}-5$ and the ${ }^{1} \mathrm{H}-{ }^{1} \mathrm{H}$ COSY data between $\mathrm{H}-6$ and $\mathrm{H}-7$. The $\mathrm{CD}$ spectrum almost indicated the same curve to that of 2 , indicating the absolute configuration of the backbone in $\mathbf{5}$ to be the same to that of 2 (Fig. 4). However, the stereochemistry of C-18 could not be established currently.

Compounds 1-5 were evaluated for their antibacterial activities against Escherichia coli, Staphylococcus aureus, Salmonella enterica, and Pseudomonas aeruginosa. As a result, compounds 1-3 showed antibacterial activity with MIC values in a range of $16-128 \mu \mathrm{g} / \mathrm{mL}$ (Table 3 ).

\section{Experimental Section}

\subsection{General Experimental Procedures}

Optical rotations were measured on a Rudolph Autopol IV polarimeter. UV spectra were obtained on a UH5300 UV-VIS Double Beam Spectrophotometer. IR spectra were obtained by using a Shimadzu Fourier Transform Infrared spectrometer with $\mathrm{KBr}$ pellets. NMR spectra were acquired with a Bruker Avance III 600 instrument. CD spectra were recorded with an Applied Photophysics Chirascan-Plus spectrometer. High resolution electrospray ionization mass spectra (HRESIMS) were recorded on a LC-MS system consisting of a $\mathrm{Q}$ Exactive ${ }^{\mathrm{TM}}$ Orbitrap mass spectrometer with an ESI ion source used in ultra-high resolution mode $(140,000$, at $m / z$ 200) and a Dionex UltiMate 3000 RSLC UPLC system. Silica gel (200-300 mesh and 500-800 mesh), RP-18 gel (40-75 $\mu \mathrm{m})$ and Sephadex LH-20 were used for column chromatography (CC). Preparative HPLC was performed on an Agilent 1260 liquid chromatography system with a Zorbax SB-C18 $(5 \mu \mathrm{m}, 9.4 \times 150 \mathrm{~mm})$ column, a Daicel chiral column (AS-H, $5 \mu \mathrm{m}, 4.6 \times 250 \mathrm{~mm}$ ) and a DAD detector.

\subsection{Fungal Material and Cultivation Conditions}

Fruiting bodies of $P$. candolleana were collected at Jingdong of Yunnan Province, China in 2003. They were identified by Prof. Zhu-Liang Yang of Kunming Institute of Botany, Chinese Academy of Sciences. The voucher specimen (NO. CGBWSHF00118.2) was deposited at School of Pharmaceutical Sciences, South-Central University for Nationalities. The strains were cultured in PDA and stored at $-4{ }^{\circ} \mathrm{C}$. Culture medium was composed of glucose (5\%), pork pepton $(0.15 \%)$, yeast $(0.5 \%), \mathrm{KH}_{2} \mathrm{PO}_{4}(0.05 \%)$ and $\mathrm{MgSO}_{4}$ $(0.05 \%)$. Initial $\mathrm{pH}$ was adjusted to 6.0 , the fermentation was first carried out on an erlenmeyer flask for 6 days till the mycelium biomass reached to the maximum. Then it was transferred to rice medium at $24{ }^{\circ} \mathrm{C}$ in dark culture for 40 days. The rice medium in each $250 \mathrm{~mL}$-Erlenmeyer flask was composed of rice $(50 \mathrm{~g})$ and water $(50 \mathrm{~mL})$. A total of 180 bottles were used in this study.

\subsection{Extraction and Isolation}

The rice fermentation $(9 \mathrm{~kg})$ was extracted four times with EtOAc. The organic layer was evaporated to give a crude extract $(90 \mathrm{~g})$. The extract was subjected to silica gel CC (200-300 mesh) eluted with a gradient solvent system of petroleum ether ( $\mathrm{PE}) / \mathrm{Me}_{2} \mathrm{CO}$ (from 20:1 to 1:1) to afford eight fractions A-H. Fraction $\mathrm{C}(3.8 \mathrm{~g})$ was isolated by $\mathrm{CC}$ over silica gel using $\mathrm{PE} / \mathrm{Me}_{2} \mathrm{CO}(6 / 1)$ to give subfractions $\mathrm{C} 1-\mathrm{C} 6$. Compound $\mathbf{1}$ was deposited from fraction $\mathrm{C} 4$ as 
Table 3 Antibacterial activity of 1-5 (MIC, $\mu \mathrm{g} / \mathrm{mL})$

\begin{tabular}{lrccc}
\hline Comp & Escherichia coli & $\begin{array}{l}\text { Staphylococcus } \\
\text { aureus subsp. aureus }\end{array}$ & $\begin{array}{l}\text { Salmonella enterica } \\
\text { subsp. enterica }\end{array}$ & $\begin{array}{l}\text { Pseudomonas } \\
\text { aeruginosa }\end{array}$ \\
\hline $\mathbf{1}$ & 16 & 64 & 64 & 16 \\
$\mathbf{2}$ & 16 & 16 & 32 & 16 \\
$\mathbf{3}$ & 64 & 128 & 128 & 64 \\
$\mathbf{4}$ & $>128$ & $>128$ & $>128$ & $>128$ \\
$\mathbf{5}$ & $>128$ & $>128$ & $>128$ & $>128$ \\
Chloramphenicol & 4 & 4 & 4 & 1 \\
\hline
\end{tabular}

colorless crystals ( $6 \mathrm{mg}$; purity $>95 \%)$. Fraction E (4 g) was first isolated by silica gel CC (200-300 mesh) eluted with $\mathrm{PE} / \mathrm{Me}_{2} \mathrm{CO}(5 / 1)$ to give five subfractions E1-E5. Fraction E2 (800 mg) was further isolated by CC using RP-C18 silica gel $\left(\mathrm{MeOH} / \mathrm{H}_{2} \mathrm{O}\right.$ from $6 / 4$ to $\left.9 / 1\right)$ to give subfractions E2a-E2e. HPLC preparation $\left(\mathrm{MeCN} / \mathrm{H}_{2} \mathrm{O}\right.$ from $7 / 3$ to $8 / 2$ in $20 \mathrm{~min}$ ) on fraction E2d (82 $\mathrm{mg}$ ) afforded compounds $3\left(1.8 \mathrm{mg}\right.$, retention time $\left(\mathrm{t}_{R}\right)=12.1 \mathrm{~min}$; purity $90 \%), 4\left(2.8 \mathrm{mg}, \mathrm{t}_{R}=12.8 \mathrm{~min}\right.$; purity $\left.90 \%\right)$, and 2 (4.3 $\mathrm{mg}$, $\mathrm{t}_{R}=14.6 \mathrm{~min}$; purity $\left.>95 \%\right)$. Fraction E2e (70 mg) was separated by CC over Sephadex LH-20 (MeOH) to give a mixture. The mixture was subjected to HPLC $\left(\mathrm{MeCN} / \mathrm{H}_{2} \mathrm{O}\right.$ from $7 / 3$ to $8 / 2$ in $20 \mathrm{~min}$ ) to give compound $\mathbf{5}(2.6 \mathrm{mg}$, $\mathrm{t}_{R}=15.1 \mathrm{~min}$; purity $90 \%$ ).

\subsection{Spectroscopic Data of Compounds}

\subsubsection{Psathyrellin A (1)}

Colorless crystals $(\mathrm{MeOH}) ;[\alpha]_{\mathrm{D}}^{15}-208.1$ ( $\left.c 0.22, \mathrm{MeOH}\right)$; $\mathrm{UV}(\mathrm{MeOH}) \lambda_{\max }(\log \varepsilon) 192$ (3.36), 244 (3.18) nm; IR (KBr) $\nu_{\max } 3421,3349,2829,1710,1702,1640,1462$, $1038 \mathrm{~cm}^{-1}$; ${ }^{1} \mathrm{H}(600 \mathrm{MHz})$ and ${ }^{13} \mathrm{C} \mathrm{NMR}(150 \mathrm{MHz})$ data (methanol- $d_{4}$ ), see Table 1; HRESIMS $m / z$ 333.20584 $[\mathrm{M}+\mathrm{H}]^{+}$(calcd for $\mathrm{C}_{20} \mathrm{H}_{29} \mathrm{O}_{4}^{+}, 333.20604$ ).

\subsubsection{Psathyrellin B (2)}

Colorless crystals $(\mathrm{MeOH}) ;[\alpha]_{\mathrm{D}}^{15}-239.2($ c $0.18, \mathrm{MeOH})$; $\mathrm{UV}\left(\mathrm{H}_{2} \mathrm{O}\right) \lambda_{\text {max }}(\log \varepsilon) 190$ (3.34), 252 (3.20), 282 (2.86) $\mathrm{nm}$; ECD $(\mathrm{MeOH}) \lambda_{\max }(\Delta \varepsilon) 223(+49), 251(+45), 287$ (-39), 339 (-27) nm; IR (KBr) $\nu_{\max } 3432,3346,2910,1711$, $1706,1642,1446,1036 \mathrm{~cm}^{-1} ;{ }^{1} \mathrm{H}(600 \mathrm{MHz})$ and ${ }^{13} \mathrm{C}$ NMR (150 MHz) data (methanol- $d_{4}$ ), see Table 1; HRESIMS $m / z$ $331.19031[\mathrm{M}+\mathrm{H}]^{+}$(calcd for $\mathrm{C}_{20} \mathrm{H}_{27} \mathrm{O}_{4}{ }^{+}, 331.19039$ ).

\subsubsection{Psathyrellin C (3)}

Yellow oil; $[\alpha]_{\mathrm{D}}^{15}-182.9(c 0.12, \mathrm{MeOH}) ; \mathrm{ECD}(\mathrm{MeOH})$ $\lambda_{\text {max }}(\Delta \varepsilon) 209$ (-33), $224(+26), 287(-29), 341(-8) \mathrm{nm} ;{ }^{1} \mathrm{H}$ $(600 \mathrm{MHz})$ and ${ }^{13} \mathrm{C}$ NMR $(150 \mathrm{MHz})$ data (methanol- $\left.d_{4}\right)$, see Table 1; HRESIMS $m / z$ 349.20093 [M+H] ${ }^{+}$(calcd for $\left.\mathrm{C}_{20} \mathrm{H}_{29} \mathrm{O}_{5}{ }^{+}, 349.20095\right)$.

\subsubsection{Psathyrellin D (4)}

Yellow oil; $[\alpha]_{\mathrm{D}}^{15}-221.9(c 0.14, \mathrm{MeOH})$; ECD $(\mathrm{MeOH})$ $\lambda_{\max }(\Delta \varepsilon) 222(+20), 243(+22), 287(-15), 338(-12)$ $\mathrm{nm} ;{ }^{1} \mathrm{H}(600 \mathrm{MHz})$ and ${ }^{13} \mathrm{C}$ NMR $(150 \mathrm{MHz})$ data (methanol- $\left.d_{4}\right)$, see Table 1; HRESIMS $m / z$ 411.17749 $[\mathrm{M}+\mathrm{Na}]^{+}$ (calcd for $\mathrm{C}_{22} \mathrm{H}_{28} \mathrm{O}_{6} \mathrm{Na}^{+}, 411.17781$ ).

\subsubsection{Psathyrellin E (5)}

Yellow oil; $[\alpha]_{\mathrm{D}}^{15}-292.4(c 0.12, \mathrm{MeOH})$; ECD $(\mathrm{MeOH})$ $\lambda_{\text {max }}(\Delta \varepsilon) 221(+27), 242(+31), 290(-24), 338(-18) \mathrm{nm}$; ${ }^{1} \mathrm{H}(600 \mathrm{MHz})$ and ${ }^{13} \mathrm{C} \mathrm{NMR}(150 \mathrm{MHz})$ data (methanol- $\left.d_{4}\right)$, see Table 1; HRESIMS $m / z 373.20084[\mathrm{M}+\mathrm{H}]^{+}$(calcd for $\mathrm{C}_{22} \mathrm{H}_{29} \mathrm{O}_{5}^{+}, 373.20095$ ).

\subsubsection{X-Ray Crystallographic Data for Psathyrellin A (1)}

$\mathrm{C}_{20} \mathrm{H}_{28} \mathrm{O}_{4}, M=332.42, a=14.0862(3) \AA, b=7.26370(10)$ $\AA, c=17.3636(3) \AA, \alpha=90^{\circ}, \beta=99.5460(10)^{\circ}, \gamma=90^{\circ}$, $V=1752.01(5) \AA^{3}, T=100$.(2) $\mathrm{K}$, space group $P 1211, Z=4$, $\mu(\mathrm{Cu} \mathrm{K} \alpha)=0.692 \mathrm{~mm}^{-1}, 33652$ reflections measured, 6741 independent reflections $\left(R_{\text {int }}=0.0259\right)$. The final $R_{l}$ values were $0.0306[I>2 \sigma(I)]$. The final $w R\left(F^{2}\right)$ values were 0.0799 [I>2 $\sigma(I)]$. The final $R_{l}$ values were 0.0307 (all data). The final $w R\left(F^{2}\right)$ values were 0.0800 (all data). The goodness of fit on $F^{2}$ was 1.056. Flack parameter $=0.05(3)$. CCDC: 2068966 (www.ccdc.cam.ac.uk).

\subsubsection{X-Ray Crystallographic Data for Psathyrellin B (2)}

$\mathrm{C}_{20} \mathrm{H}_{26} \mathrm{O}_{4}, M=330.41, a=8.0026(8) \AA ⿻ 8.3729(9) \AA$, $c=14.4078(15) \AA, \alpha=90.00^{\circ}, \beta=105.783(3)^{\circ}, \gamma=90.00^{\circ}$, $V=929.00(17) \AA^{3}, \mathrm{~T}=150 .(2) \mathrm{K}$, space group $P 1211$, $Z=2, \mu(\mathrm{CuK} \alpha)=1.54178 \mathrm{~mm}^{-1}, 12059$ reflections measured, 3552 independent reflections $\left(R_{\text {int }}=0.0456\right)$. The final $R_{1}$ values were $0.0559[I>2 \sigma(I)]$. The final $R_{1}$ values were 0.0415 (all data). The final $w R\left(F^{2}\right)$ values were 0.1156 (all data). The goodness of fit on $F^{2}$ was 1.092 . Flack 
parameter $=-0.12(14)$. CCDC: 2068967 (www.ccdc.cam. ac.uk).

\subsection{Antibacterial Assay}

The tested bacteria strains Escherichia coli ATCC25922, Staphylococcus aureus subsp. aureus ATCC29213, Salmonella enterica subsp. enterica ATCC14028, Pseudomonas aeruginosa ATCC27853 were purchased from China General Microbiological Culture Collection Center, (CGMCC). All these strains were cultured in Mueller Hinton broth (MHB) (Guangdong Huankai Microbial Sci. \& Tech. Co., Ltd.) at $37{ }^{\circ} \mathrm{C}$ overnight with shaking (200 rpm). A sample of each culture was then diluted 40-fold in fresh MHB broth and incubated with shaking $(200 \mathrm{rpm})$ at $37{ }^{\circ} \mathrm{C}$ for $2.5 \mathrm{~h}$. The resultant mid-log phase cultures were diluted to a concentration of $5 \times 10^{5} \mathrm{CFU} / \mathrm{mL}$, then $50 \mathrm{~mL}$ was added to each well of the compound-containing plates. The minimum inhibition concentration (MIC) was determined by measuring bacterial growth after $24 \mathrm{~h}$ on performing 1:2 serial dilutions of each compound ranging from 1 to $128 \mu \mathrm{g} / \mathrm{mL}$. Chloramphenicol was used as a positive control.

Supplementary Information The online version contains supplementary material available at https://doi.org/10.1007/s13659-021-00316-x.

Acknowledgements The work is financially supported by the National Key Research and Development Program of China (Grant No. 2017YFC1704007). The authors thank Analytical \& Measuring Centre, South-Central University for Nationalities for the spectra measurements.

\section{Declarations}

Conflict of interest The authors declare no conflict of interest.

Open Access This article is licensed under a Creative Commons Attribution 4.0 International License, which permits use, sharing, adaptation, distribution and reproduction in any medium or format, as long as you give appropriate credit to the original author(s) and the source, provide a link to the Creative Commons licence, and indicate if changes were made. The images or other third party material in this article are included in the article's Creative Commons licence, unless indicated otherwise in a credit line to the material. If material is not included in the article's Creative Commons licence and your intended use is not permitted by statutory regulation or exceeds the permitted use, you will need to obtain permission directly from the copyright holder. To view a copy of this licence, visit http://creativecommons. org/licenses/by/4.0/.

\section{References}

1. M. Kuo, Psathyrella candolleana. http://www.mushroomexpert. com/psathyrella_candolleana.html

2. M.N. Al-Habib, J.C. Holliday, D. Tura, J. Med. Mushrooms 16, 617-622 (2014)

3. M.N. Al-Habib, J.C. Holliday, M.S. Aladahmy, Int. J. Med. Mushrooms 20, 749-759 (2018)

4. X. Yin, T. Feng, Z.H. Li, Y. Leng, J.K. Liu, Nat. Prod. Bioprospect. 4, 149-155 (2014)

5. Y.P. Liu, Q. Dai, W.X. Wang, J. He, Z.H. Li, T. Feng, J.K. Liu, J. Nat. Prod. 83, 1725-1729 (2020)

6. Y. Feng, F.X. Ren, S.B. Niu, L. Wang, L. Li, X.Z. Liu, Y.S. Che, J. Nat. Prod. 77, 873-881 (2014)

7. Y.P. Liu, Q. Dai, C.J. Pu, M. Wang, Z.H. Li, J.K. Liu, T. Feng, Nat. Prod. Comm. 14, 1-4 (2019)

8. H.X. Yang, H.L. Ai, T. Feng, W.X. Wang, B. Wu, Y.S. Zheng, H. Sun, J. He, Z.H. Li, J.K. Liu, Org. Lett. 20, 8069-8072 (2018)

9. J. He, M.S. Yang, W.X. Wang, Z.H. Li, W.A.M. Elkhateeb, T.C. Wen, H.L. Ai, T. Feng, RSC Adv. 9, 128-131 (2019)

10. W.X. Wang, Z.H. Li, T. Feng, J. Li, H. Sun, R. Huang, Q.X. Yuan, H.L. Ai, J.K. Liu, Org. Lett. 20, 7758-7761 (2018)

11. T. Feng, J. He, H.L. Ai, R. Huang, Z.H. Li, J.K. Liu, Nat. Prod. Bioprospect. 5, 205-208 (2015)

12. M. Wang, Z.H. Li, M. Isaka, J.K. Liu, T. Feng, Nat. Prod. Bioprospect. 11, 215-222 (2021)

13. C. Shi, Y.L. Peng, J. He, Z.H. Li, J.K. Liu, T. Feng, Nat. Prod. Bioprospect. 11, 235-241 (2021)

14. H. Zhang, M.H. Yang, Y. Li, X.B. Cheng, Y.H. Pei, L.Y. Kong, Fitoterapia 133, 219-244 (2019) 